\title{
電流ステップ法によるコルベ電解反応の研究（II） 白金電極におけるプロピオン酸塩水溶液の陽極酸化反応
}

\author{
椚章, *大橋邦夫*, 長浦茂男* \\ Studies of the Kolbe Reaction by Current-Step Method (II) \\ Anodic Oxidation of an Aqueous Propionate \\ Solution at a Platinum Electrode
}

Akira KUnUGi*, Kunio OHASH* and Shigeo NAGAURA*

\begin{abstract}
The current-step method presented in the previous paper was applied to the study of the electrode process on a platinum anode in an aqueous propionate solution. Some results of aqueous acetate solutions, $1 \mathrm{~N} \mathrm{H}_{2} \mathrm{SO}_{4}$ and $1 \mathrm{NNaOH}$ were included for making a comparision. It was shown that behaviours of resistance, time constant, and capacitance of electrode reactions as a function of the current density of dc polarization in an aqueous propionate solution were similar to those in the acetate solution, indicating that both the Kolbe reaction and oxygen-evolution reaction in the aqueous propionate solution are controlled by a charge-transfer process. The value of $R T / \alpha n F$ obtained by this method agreed well with the value obtained by Tafel plots for the Kolbe reaction region, but the large discrepancy between above two values was shown for the oxygen-evolution region. The values of double-layer capacitance for the propionate solution over various current densities were equal to about two-third of these of the acetate solution, and decreased to about $1 / 2 \sim 1 / 3$ when the main reaction changed from the oxygenevolution to the Kolbe reaction. The mechanisms of the Kolbe reaction of propionate and acetate in aqueous solutions were discussed.
\end{abstract}

\section{1 緒言 (Introduction)}

プロピオン酸イオンの陽極酸化反応に関しては，ビニ ル化合物や芳香族化合物の共存下での電解酸化より,こ の陽極酸化反応の過程にはプロピオニルオキシラジカル とエチルラジカルが存在しここれらのラジカル間の不均 化でエチレンが生成することを示した ${ }^{1), 2)}$ また，この 陽極反応の律速段階についてはインピーダンス測定法よ り電荷移動過程が律速段階であることも示した ${ }^{3)}$ 。本研 究では, 前報〉と同一の電流ステップ法による電極反応 の解析法を用いて，白金電極におけるプロピオン酸塩水 溶液の陽極酸化反応を研究し, 酢酸塩の陽極酸化反応上 比較検討およびインピーダンス測定法上の比較検討を加 えた.

* 大阪市立大学工学部(大阪市住吉区杉本町) Department of Applied Chemistry, Faculty of Engineering, Osaka City University (Sugimoto-cho, Sumiyoshi-ku, Osaka)

\section{2 実験 (Experimental)}

電解液には $1.0 \mathrm{~mol} / l$ のプロピオン酸ナトリウムを含 むプロピオン酸水溶液（pH 5.5）を用いた。また，参 照のため $1 N$ 硫酸 および $1 N$ カセイソーダ水溶液に ついても測定を行った. 用いた試薬は市販特級品をその まま使用し, 水は 2 回蒸留して使用した。作用極には前 報”と同一の白金線電極 (見加けの作用表面積 $0.39 \mathrm{~cm}^{2}$ ) を使用した。本実験に用いた測定装置や，測定方法は前 報》と同一にした。

\section{3 結 果 (Results)}

前報》と同一の方法によって，直流電流 $i$ で分極し た電極に $\Delta i$ なる大きさのかなり長いパルス電流を印加 し, 電流ステップしたときの電極電位の時間変化 $\Delta E(t)$ を測定し，それぞれの $i$ に対する時定数 $て と \Delta E_{\infty}$ を 
$1 / i\left(\mathrm{~cm}^{2} / \mathrm{mA}\right)$

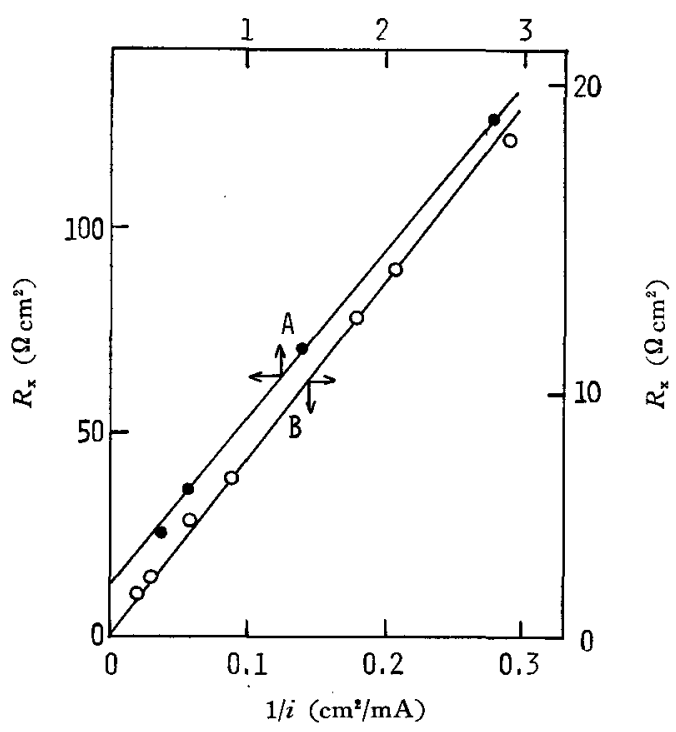

Fig. 1 Plots of resistance vs. reciprocal of current density for $1 M$ sodium propionate solution ( $\mathrm{pH}$ 5.5) and $\mathrm{Pt}$ electrode (progressive increase in current)

A : Oxygen -evolution region

B : Kolbe region, Temp. : $17^{\circ} \mathrm{C}$

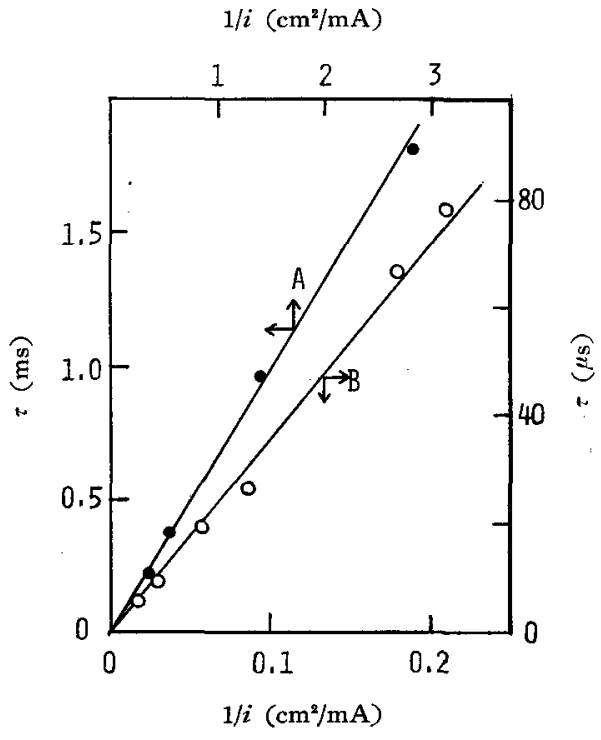

Fig. 2 Plots of time constant vs. reciprocal of current density for propionate solution (progressive increase in current)

A : Oxygen-evolution region

$B$ : Kolbe region

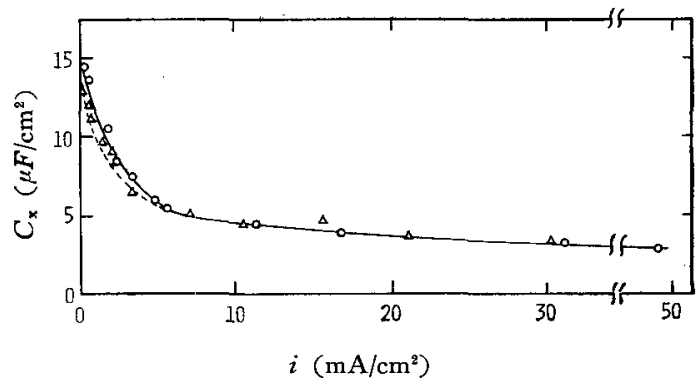

Fig. 3 Plots of capacitance vs. current density for propionate solution

$\mathrm{O}$ : Progressive increase in current.

$\Delta$ : Progressive decrease in current

求め, それらの值より反応抵抗 $R_{\mathbf{x}}\left(=\Delta E_{\infty} / \Delta i\right)$ および

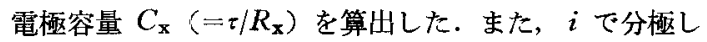
たときの準定常電位の值を Tafel プロットし, Tafel $b$ 保数を求めた。

\section{$3.1 R_{\mathrm{x}} \sim 1 / i$ の闺係}

プロピオン酸塩水溶液 $(1.0 \mathrm{~mol} / l, \mathrm{pH} 5.5)$ を白金電 極上で， $i$ を段階的に堌加させて陽分極した場合の $R_{\mathrm{x}}$ 〜1/i のプロットは Fig. 1 に示すように, コルべ反応 領域では原点を通る直線関係を示したが, 酸素発生領域 では原点を通らない関倸を示した。他方, $i$ を段階的に 減少させて測定した場合にも，同様な関係が得られた。 類似の関係は酢酸㙁の場合にも観測されている゙”.

\section{$3.2 \tau \sim 1 / i$ の成标}

電流増加の場合の $\tau \sim 1 / i$ のプロットは Fig. 2 に示 すように, コルべ領域と酸素発生領域のいずれも原点を 通る直線関係を示した。電流減少の場合も同様な関係が 得られた。このことは，前報の理論 ${ }^{4}$ 上り少くともプロ ピオン酸イオンの晹拯酸化反応は表面化学反応過程律速 ではなく電何移動過程律速であることを示している.酸 素発生反応については後で詳述する。

\section{$3.3 C_{\mathrm{x}} \sim i$ の成保}

$C_{\mathrm{x}} \sim i$ のプロッドは Fig. 3 に示すよ5に, $i$ の増加 とともに $C_{\mathbf{x}}$ 㳔减少し，iの大きい領城でほぼ一定值に なる.また，電流增加と減少の場合とでは， $i$ の小さい 領域（酸素発生領域）で $C_{\mathbf{x}}$ は多少の差異を示したが, 酢酸塩の場合ほど大きな差はなかった（前報の Fig. 7 参照).

前報4で述べたように，電荷移動過程律速の場合に法 $C_{\mathrm{x}}$ は $i$ に無関倸に一定である.しかるに,このよ5に゙ 酸素発生領域で特に $i$ の増大とともに $C_{\mathrm{x}}$ が減少する のは酸素発生反応とは直接関係のないプロピオン酸イオ ンが電極に吸着している水（あるいは水酸イオン）と交 換吸着し，その吸着量が電流（電位）とともに堌大する ためかあるいは Fig. 1 に示したように酸素発生領域の 


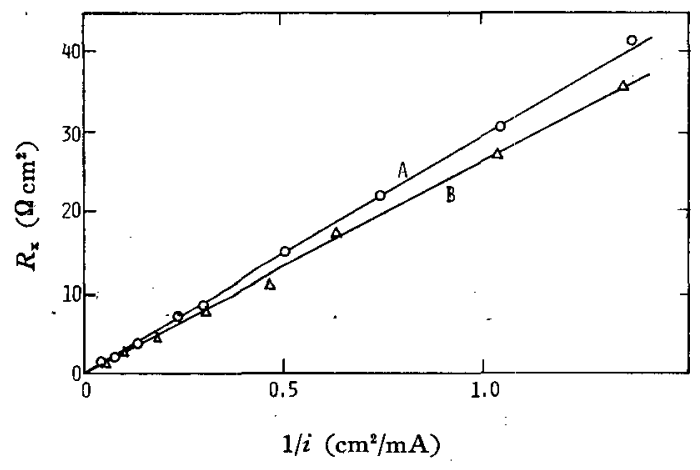

Fig. 4 Plots of resistance vs. reciprocal of current density (progressive increase in current)

A : $1 \mathrm{~N} \mathrm{H}_{2} \mathrm{SO}_{4}, \quad \mathrm{~B}: 1 N \mathrm{NaOH}$

Electrode : Pt, Temp. : $25^{\circ} \mathrm{C}$

$R_{\mathrm{x}} \sim 1 / i$ の関保が異常であったため，見かけ上 $C_{\mathrm{x}}$ の減 少をもたらしたものと考㝋られる. 少くとも， $i$ の増大 とともに $C_{\mathbf{x}}$ が増加しない限り, 表面化学反応過程は律 速段階ではないと結論される，したがって，上記の結果 より，測定した $C_{\mathbf{x}}$ の值は電気二重層容量の値となる.

\section{4 硫䣹亡カセイソータ溶液中での酸素発生反応}

$1 N$ 硫酸および $1 N$ カセイソーダ水溶液の 白金電極 に括ける酸素発生反応を同様に電流ステップ法によって 検討した. それらの結果は, Fig. 4 亿示すよ5に $R_{\mathrm{x}}$ 〜 1/i のプロットは原点を通る直線関係を示した。 また， $\tau \sim 1 / i$ のプロットも原点を通る直線関倸を示し, さらに

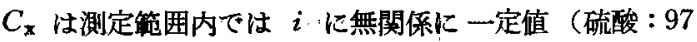
$\mu F / \mathrm{cm}^{2}$ ，カセイソーダ: $\left.140 \mu F / \mathrm{cm}^{2}\right)$ を示した. した がって，これらの水溶液中での酸素発生反応はこの電流 ステップ法の解析からも電荷移動過程が律速段階である ことがわかった。

律速段階が電荷移動過程あるいは表面化学反応過程の いずれで西っても， $R_{\mathbf{x}} \sim 1 / i$ の関倸仙原点を通る直線と なるのに，酶酸塩さや やプロピオン酸塩水溶液中での酸素 発生反応に 対する $R_{\mathrm{x}} \sim 1 / i$ のプロット性原点を通らな い関係を示した。したがって，こ机らの有機酸塩共存下 での酸素発生反応は無機酸やアルカリ中での酸素発生反 応よりもかなり複雑な反応であると考えられる。すなる ち，電極に吸着した酶酸イオンやプロピオン酸イオンが 酸素発生に対する電極の有効表面積を減少させるだけで はなく，酸素発生反応の抵抗を大きくさせるように作用 するむのと考光ることができる*1、しかる，その作用は これらの有機酸イオンの吸着量の増加とともに大きくな るものと考えられる。この作用の大きさ圾栖できない

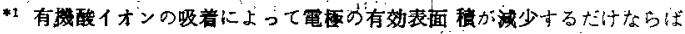

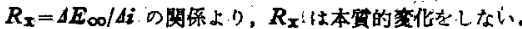

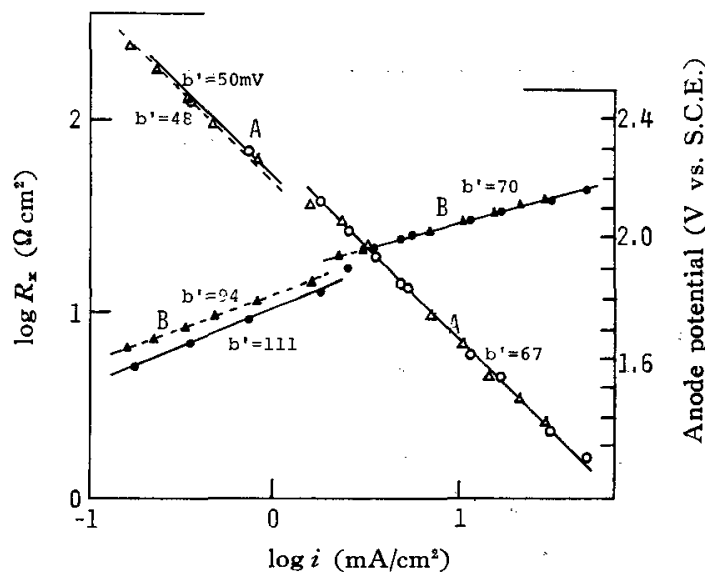

Fig. 5 Logarithmic plots of resistance vs. current density (A) and Tafel plots (B) for $1 M$ sodium propionate solution $(\mathrm{pH} \mathrm{5.5)}$

0,0 : Progressive increase in current $\triangle, \triangle$ : Progressive decrease in current Temp. : $17^{\circ} \mathrm{C}, b^{\prime}=R T / \alpha n F$

がこれらの作用を補正するならば， $R_{\mathrm{x}} \sim 1 / i$ のプロッ トが原点を通るよ5になることが尔想される。したがっ て,インピーダンス測定法の結論 ${ }^{3), 5)}$ と同様に，酢酸塩 およびプロピオン酸塩水溶液中での酸素発生反応は電荷 移動過程律速であると結論した。

\section{4 考察 (Discussion)}

\section{$4.1 R T / a n F$}

$R T / \alpha n F$ (以下 $b^{\prime}$ とする) の值は $R_{\mathrm{x}} \sim 1 / i$ のこう配 上り求められるが,“前述のようにプロピオン酸塩水溶液 中での酸素発生反応に対しては， $R_{\mathbf{x}} \sim 1 / i$ の関倸は原点 を通らなかったため求めることができなかった，そこで Fig. 5 亿示すように, $\log R_{\mathrm{x}} \sim \log i$ プロットし, 電荷 移動過程律速であると結論したのでこう配-1の直線を引 き $b^{\prime}$ の値を求めた。 また, Tafel プロットから $b^{\prime} の$ 值を求めた：これらの值は図中に示した. $\log R_{\mathrm{x}} \sim \log i$ 曲線と Tafel 曲線からわかるように, Iog $i$ の增大とと むに $\log R_{\mathrm{x}}$ は直線的に減少するが，約 $1.8 \mathrm{~V}$ (vs. S.C.E.) から，すなわちコルベ反応が開始する電位より む早な電位からコルべ反応領域の線上に $\log R_{\mathrm{x}}$ が移 る. したがって，酸素発生反応に対しては $2 つ の . b^{\prime}$ の 値が得られる。いずれの值も，Tafel プロットより求め た $b^{\prime}$ の值の $1 / 2$ 以下である. 他方，コルべ反応領城で は, 電流ステップ法から求㫑た $b^{\prime}$ の值と Tafel プロッ トから求めた $b^{\prime}$ の值はよ々一致を示した。 同様な結果 は酢酸塩水溶液の場合に年得られた (Fig. 6)。このよ 


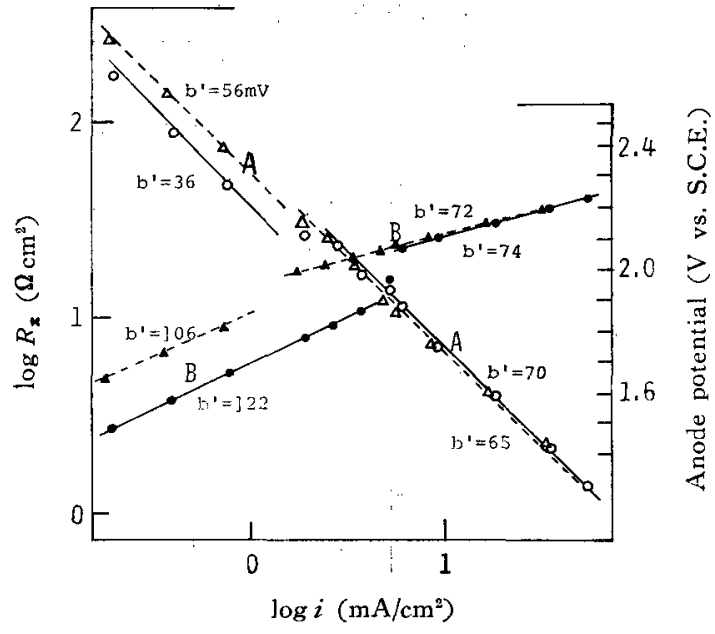

Fig. 6 .Logarithmic plots of resistance vs. current density (A) and Tafel plots (B) for $1 M$ sodium acetate solution (pH 5.5)

0.0 : Progressive increase in current

$\triangle, \triangle$ : Progressive decrease in current

Temp. : $17^{\circ} \mathrm{C}, b^{\prime}=R T / \alpha n F$

Table 1 Values of $R T / \alpha n F$ obtained by different methods

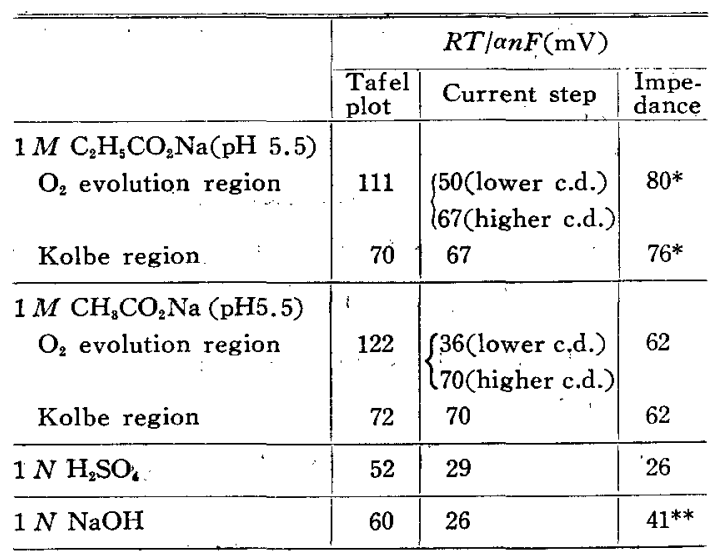

$*: \mathrm{pH} 6.0, * *: 1 \mathrm{~N} \mathrm{KOH}$

らに，測定法によって $b^{\prime}$ の值がコルベ領城では一致す るが酸素発生領域では一致しないことがインピーダンス 測定法の場合にも観測されている゙3. 硫酸やアルカリ溶 液中での酸素発生反店の $b^{\prime}$ d測定法の不一致が観測さ れた。 各種测定法による $b^{\prime}$ の值を Table 1 にまとめ て示した.

このような測定法の逗いによる $b^{\prime}$ の不一致について 多少検討を試みた. Fig. 7 (プロピオン酸塩) と Fig. 8

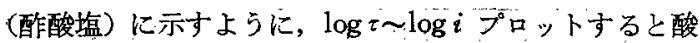
素発生反応からコルべ反応に移るときに $\log \tau$ が急激に

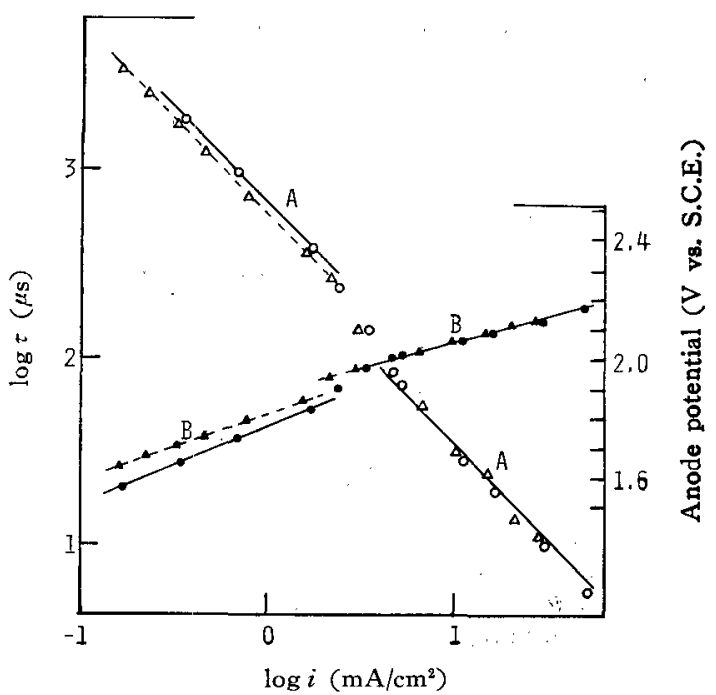

Fig. 7 Logarithmic plots of time constant vs. current density (A) and Tafel plots (B) for propionate solution

in current

0,0 : Progressive increase in current
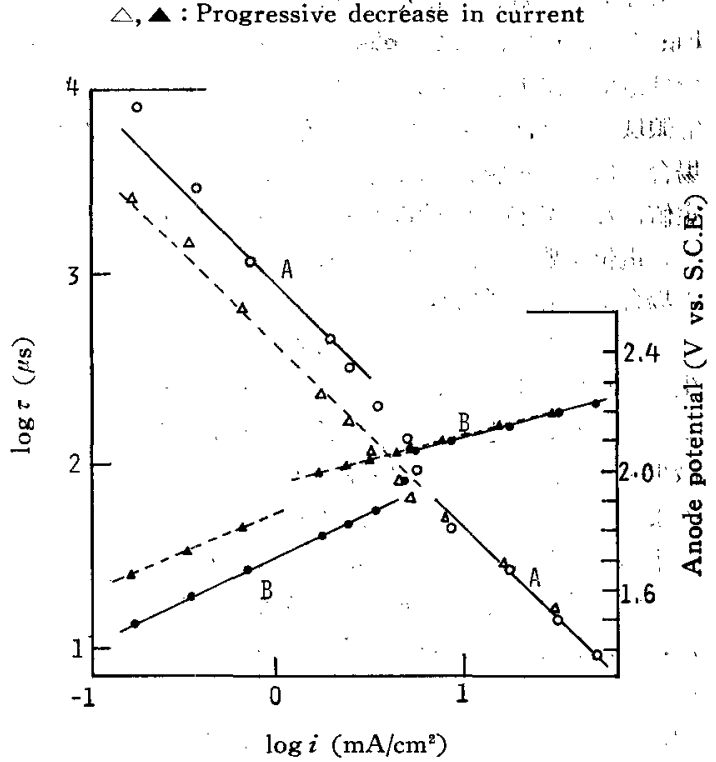

Fig. 8 Logarithmic plots of time constant vs. current density (A) and Tafel plots (B) for acetate solution

$0,0:$ Progressive increase in current

$\triangle, \Delta$ : Progressive decrease in current

隇少することがわかる：このことと方 の不一致とは関 係があると考えられるすなわち；コルベ反忘に対して はヶは比較的小さいため; 定常法 (Tafel プロット法) と非定常法 (電流ステップ法, インピーダンス法) から 


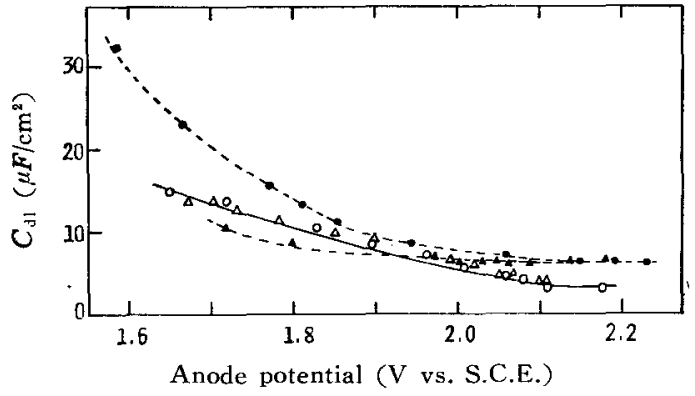

Fig. 9 Plots of double-layer capacitance vs. anode potential

$\mathrm{O}_{3} \triangle$ : Propionate solution

, $\Delta$ : Acetate solution

0.0 : Progressive increase in current

$\triangle, \triangle$ : Progressive decrease in current

求めた $b^{\prime}$ の值は一致するが, 酸素発生反応に対しては $\tau$ が比較的大きいため，定常法と非定常法の差が大きく なると考えた。

\section{$4.2 \pi$ 気二重層容量}

電極電位に対して電気二重層容量をプロットすると，

Fig. 9 に示すように, 酢酸塩の場合に汢酸素発生領域 では電位の増大とともに二重層容量は減少し，コルベ反 応領域ではほぼ一定になった。他方, プロピオン酸塩の 場合には, 二重層容量は電位の増大とともに減少し, 一 定值になる電位は酢酸塩の場合よりも貲な電位であっ た，電位全般にわたって，酢酸塩の方がプロピオン酸塩 の場合よりも二重層容量は大きかった.

インピーダンス測定法から求めた二重層容量は酸素発 生反応からコルベ反応に移行すると約 $1 / 2 \sim 1 / 3$ に減少 したのに対し，電流ステップ法では上記のよ5に連綂的 堿少を示した.しかし，電流ステップ法の場合でも，次 のよ5にして二重層容量を求めるとインピーダンス法か ら求めた值とほぼ一致し, 陽極反応が酸素発生からコル ベ反応に移行すると二重層容量が減少することがわかっ

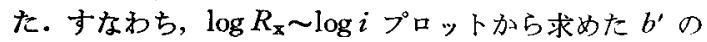
值と $\tau \sim 1 / i$ のプロットのこう配とから求めた。それら の值とインピーダンス法から求めた值を Table 2 亿去 とめた.この方法と $\tau / R_{\mathrm{x}}$ から求めた二重層容量の違い は, 酸素発生領域に扔ける $R_{\mathrm{x}} \sim 1 / i$ 関係の異常性によ るものと考えられる.

\section{3 コルへ雪解反応機搆}

白金電極におけるプロピオン酸イオンの陽極酸化反応 は電荷移動過程律速であり，酸素発生反応からコルべ反 肉に移行すると二重層容量が約 $1 / 2$ に隇少すること, 主 生成物はエチレンと炭酸ガスで, その生成比は $1: 1$ で あることおよび陽極反応の過程にはプロピオニルオキシ ラジカルとエチルラジカルが存在することから,この電
Table 2 Double-layer capacitance

\begin{tabular}{|c|c|c|}
\hline & \multicolumn{2}{|c|}{$C_{\mathrm{d} 1}\left(\mu F / \mathrm{cm}^{2}\right)$} \\
\hline & $\begin{array}{c}\text { Current-step } \\
\text { method }\end{array}$ & $\begin{array}{l}\text { Impedance } \\
\text { method }\end{array}$ \\
\hline $\begin{array}{c}1 M \mathrm{C}_{2} \mathrm{H}_{5} \mathrm{CO}_{2} \mathrm{Na}(\mathrm{pH} 5.5) \\
\mathrm{O}_{2} \text { evolution region }\end{array}$ & $\left\{\begin{array}{l}14(\text { lower c.d. }) \\
10(\text { higher c.d })\end{array}\right.$ & $11^{*}$ \\
\hline Kolbe region & 5 & $5^{*}$ \\
\hline 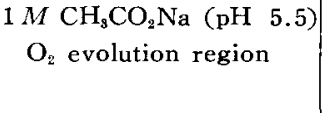 & $\left\{\begin{array}{l}26(\text { lower } \text { c.d. }) \\
14(\text { higher } \text { c.d. })\end{array}\right.$ & 25 \\
\hline Kolbe region & 7 & 10 \\
\hline $1 \mathrm{~N} \mathrm{H}_{2} \mathrm{SO}$ & 97 & 110 \\
\hline $1 \mathrm{~N} \mathrm{NaOH}$ & 140 & $60^{* *}$ \\
\hline
\end{tabular}

極反応の機構は次の3つのいずれかである*2.

( I ) $\mathrm{C}_{2} \mathrm{H}_{3} \mathrm{CO}_{2}^{-} \longrightarrow \mathrm{C}_{2} \mathrm{H}_{5} \mathrm{CO}_{2}^{-}$(ad) $\underset{\text { r.d.s. }}{\stackrel{-e}{\longrightarrow}} \mathrm{C}_{2} \mathrm{H}_{5} \mathrm{CO}_{2}$ *

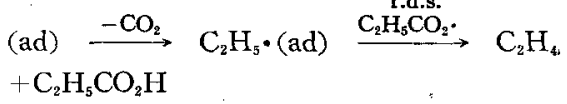

(II) $\mathrm{C}_{2} \mathrm{H}_{5} \mathrm{CO}_{2} \cdot(\mathrm{ad})+\mathrm{C}_{2} \mathrm{H}_{5} \mathrm{CO}_{2}^{-}(\mathrm{ad}$ or free $) \underset{\text { r.d.s. }}{\stackrel{-e}{\longrightarrow}}$ $\mathrm{C}_{2} \mathrm{H}_{4}+\mathrm{C}_{2} \mathrm{H}_{5} \mathrm{CO}_{2} \mathrm{H}+\mathrm{CO}_{2}$

(III) $\mathrm{C}_{2} \mathrm{H}_{5} \cdot(\mathrm{ad})+\mathrm{C}_{2} \mathrm{H}_{5} \mathrm{CO}_{2}{ }^{-}(\mathrm{ad}$ or free $) \underset{\text { r.d.s. }}{\stackrel{-e}{\longrightarrow}}$ $\mathrm{C}_{2} \mathrm{H}_{4}+\mathrm{C}_{2} \mathrm{H}_{5} \mathrm{CO}_{2} \mathrm{H}$

いずれが妥当であるかを決定することは現状では困難 ではあるが, Willson らの結果 ${ }^{6}$ やSasaki らの検討7 および既報の結果 ${ }^{2)}$ を考慮すると（I）の機構が妥当と 考えられる。

同様に，酢酸イオンの陽極酸化反応の機構については

(IV) $\mathrm{CH}_{3} \mathrm{CO}_{2} \rightarrow \longrightarrow \mathrm{CH}_{3} \mathrm{CO}_{2}^{-}$(ad) $\underset{\text { r.d.s. }}{\stackrel{-e}{\longrightarrow}} \mathrm{CH}_{3} \mathrm{CO}_{2}$ * (ad) $\stackrel{-\mathrm{CO}_{2}}{\longrightarrow} \mathrm{CH}_{3} \cdot(\mathrm{ad}) \stackrel{\mathrm{CH}_{3} \cdot}{\longrightarrow} \mathrm{C}_{2} \mathrm{H}_{6}$

(V) $\mathrm{CH}_{3} \mathrm{CO}_{2} \cdot(\mathrm{ad})+\mathrm{CH}_{3} \mathrm{CO}_{2}^{-}(\mathrm{ad}$ or free $) \underset{\text { r.d.s. }}{-\boldsymbol{e}} \rightarrow$ $\mathrm{C}_{2} \mathrm{H}_{6}+2 \mathrm{CO}_{2}$

(VI) $\mathrm{CH}_{3} \cdot(\mathrm{ad})+\mathrm{CH}_{3} \mathrm{CO}_{2}^{-}$(ad or free) $\underset{\text { r.d.s. }}{\stackrel{-e}{\longrightarrow}} \mathrm{C}_{2} \mathrm{H}_{6 \cdot}$ $+\mathrm{CO}_{2}$

のいずれかであるが，決定することは困難である．しか し，アセトキシラジカルに対するビニルモノマーの反㐫 性から検討した結果では(V) の機構が妥当であっだ. なお, メチルラジカルが電極に吸着しているのか遊離し ているのかについては Eberson ${ }^{9)} と$ Conway ら ${ }^{10)}$ の論 争がある.プロピオン酸イオンの陽極酸化反応の機構と の違、は，中間体生成物としてのメチルラジカルとエチ ルラジカルの反応性の違いによるものと思われる。 $<1429>$ (Received Jan. 16, 1974)

*2 反応式中の ad と free は電極への反応種の吸着と遊離を、また。 r.d.s. はその過程が律速であることを意味する。 


\section{文献}

1) A. Kunugi, T. Shimizu, S. Nagaura, Bu'l. Chem. Soc. Japan 43, 1298 (1970).

2) A. Kunugi, D. Yoneda, S. Nagaura, Mem. Fac. Eng.Osaka City Univ. 12, 115 (1971).

3）㭢章, 井関 進, 宗 生一郎, 谷本高敏, 長浦茂男, 日化誌 92, 768 (1971).

4）椚章, 大橋邦夫, 長浦茂男, 本誌 42,371 (1974).
5) 椆章, 井関 進, 大橋邦夫, 長浦茂男, 本誌 37, 237 (1969).

6) C.L. Willson, W. Lippincott, J. Amer. Chem. Soc. 73, 4290 (1950).

7) K. Sasaki, K. Uneyama, S. Nagaura, Electrochim. Acta 11, 891 (1966).

8）棚 章, 未笔表

9) L. Eberson, Electrochim. Acta 12, 1473 (1967).

10) A.K. Vijh, B.E. Conway, Chem. Rev. 67, 623 (1967).

\title{
スズ酸リチウムを母体とした焼結体のリチウムイオン導電性
}

\author{
高橋武彦*, 岩原弘育*, 小林伸次*
}

\section{Lithium Ion Conduction in the Sintered Oxide based on Lithium Stanate}

\author{
Takehiko TAKahashi*, Hiroyasu IWAHARA* and \\ Shinji KOBAYAȘHI*
}

\begin{abstract}
The electrical conductions in the sintered pure lithium stanate and the solid solution such as $\mathrm{Li}_{2-2 \mathrm{x}} \mathrm{Mg}_{\mathbf{x}} \mathrm{SnO}_{3}$ were investigated at high temperatures by means of concentration cell method, electrolysis and conductivity measurement. As a result, these materials were found to be lithium ion conductors as well as those in lithium titanate reported previously by the present authours.

Lithium ion conductivities of these oxides were in the order of $10^{-3} \sim 10^{-2} \mathrm{ohm}^{-1} \mathrm{~cm}^{-1}$ at $800^{\circ} \mathrm{C}$ and the values increased by substituting a small amount of di-valent cations for lithium ion.
\end{abstract}

\section{1 緒 言 (Introduction)}

すでに報告したように”，筆者らは単斜晶チタン酸り チウム $\mathrm{Li}_{2} \mathrm{TiO}_{3}$ およびそのリチウムの一部を異種カチ オンで置換した固溶焼結体が $700 \sim 800^{\circ} \mathrm{C}$ で $10^{-2} \mathrm{ohm}^{-1}$ $\mathrm{cm}^{-1}$ 程度の導電率をもつリチウムイオン導電体である ことを見いだしてきた。これと同じ結晶構造を有するむ のにスズ酸リチウム $\mathrm{Li}_{2} \mathrm{SnO}_{3}{ }^{3) \sim 6)}$ があるが，皇の高温 に括汀る遒電性についてはまだ検討されてい孙、

そこで本実験では，スズ酸リチウムおよびそのリチウ ムの一部をこれと同じ程度のイオン半径をもつ異種カチ オンで置きかえた $\mathrm{Li}_{2-\mathbf{z x}} \mathrm{M}_{\mathrm{x}} \mathrm{SnO}_{3}$ の組成比をもつ燒結 体についてリチウムイオン導電性の有無を確かめること を目的とした。ここでは $\mathrm{M}$ マグネシウム，アルミニウ ム, スズなど 2 価以上のカチオンで, 結晶の電気的中性 を保つ目的で M の含有率 $x$ およびその価数 $z$ に相当

* 名古屋大学工学部 (名古屋市千種区不老町) Department of Applied Chemistry, Faculty of Engineering, Nagoya University (Furocho, Chikusa-ku, Nagoya)
した $z x$ だけリチウム含有量を減少した組成比とした.

\section{2 実験方法 (Experimental)}

\section{1 試料焼結体の調製}

母体として二酸化スズおよび炭酸リチウムを，添加物 として, 硝酸アルミニウム, 酸化マグネシウム, 酸化亜 鉛，酸化チタンなどを出発原料とした。試薬はいずれも 特級または純度 $99.9 \%$ 以上のものを用いた．添加物の 混合をよくする目的で，上記の試薬を硝酸溶液となし， これを $\mathrm{Li}_{2} \mathrm{CO}_{3}-\mathrm{SnO}_{2}$ 混合粉末に加えて泥状とし, 乾燥 後熱分解して $800^{\circ} \mathrm{C} 10$ 時間焼成した. 烍成後, これを よく粉砕し， $2.7 \mathrm{t} / \mathrm{cm}^{2}$ の静水圧で円板状 (径約 $13 \mathrm{~mm}$, 厚さ 1 3 mm) または 円柱状（径 4 5 mm, 長さ 5 $10 \mathrm{~mm}$ ）に加圧成型して $1,100 \sim 1,200^{\circ} \mathrm{C} 10$ 時間焼成 したのち徐泠して焼結体を得た。焼成は空気中または酸 素気流中で行った.

\section{2 イオン導電性の検討}

イオン導電性の検郡は, 導電率の測定, 試料を電解質 